\title{
Evaluation of the impact by deep artesian boreholes on fresh ground waters in the terrace of Kamchiya River
}

\author{
Nikolay Stoyanov ${ }^{1}$, Mila Trayanova ${ }^{2}$, Stefan Dimovski ${ }^{1}$, Aleksey Benderev ${ }^{2}$ \\ ${ }^{1}$ University of Mining and Geology, Prof. B. Kamenov Str., Sofia, 1700. Bulgaria; e-mail: nts@mgu.bg. \\ ${ }^{2}$ Geological Institute, Bulgarian Academy of Sciences, Acad. G. Bonchev St., Block 24, Sofia 1113, Bulgaria; \\ e-mail:milat@geology.bas.bg.
}

(Accepted in revised form: November 2017)

\begin{abstract}
The area of Kamchiya River's inflow into the Black Sea has an important role not only as a natural landmark, but also as a leading factor for the national economy. It has been subjected for many years to oil and gas exploration, as well as to extraction of deep, highly mineralized waters containing chemical elements of industrial value. There are currently only few of the artesian wells related to these activities in the area. Outflowing water has very high mineralization (over $50 \mathrm{~g} / \mathrm{l}$ ). It is chlorine-sodium type and has extremely high concentrations of some components. They have formed small salt ponds around the wells, whose water and salt balance are controlled by the evaporated and infiltrated in depth water quantities. The abrupt change in the thermodynamic conditions in the porous part of the wells favours the processes of sedimentation and deposition of a substance that partially refreshes the leaking surface water and limits the possibilities for infiltration of highly mineralized waters. Salt infiltration causes enhanced local salinization of the soils and fresh groundwater accumulation in the present-day sediments of the Kamchiya River. An assessment of both the dimensions and extent of salinization in the area of the deep wells is made by applying hydrochemical and geoelectrical survey.
\end{abstract}

Stoyanov, N., Trayanova, M., Dimovski, S., Benderev, A. 2017. Evaluation of the impact by deep artesian boreholes on fresh ground waters in the terrace of Kamchiya River. Geologica Balcanica 46 (2), 125-133.

Keywords: mineral water, old wells, hydrochemistry, geoelectrical survey, groundwater pollution, Kamchiya River.

\section{INTRODUCTION}

In the $1950 \mathrm{~s}$, considerable oil and gas exploration started in Bulgaria, as more than 2000 deep boreholes were drilled. Some of them are currently free flowing and thus drain water from deep-water aquifer complexes. The outflowing water is usually characterized by enhanced mineralization and has different substantial composition compared to the fresh water. The present study aims to determine the impact of the deep drilling on groundwater in the terrace of Kamchiya River, which was not only oil and gas exploration site, but also a site for the exploration and exploitation of iodine-bromine waters. A quantitative assessment of the impact of two boreholes in the area, with very high mineralization of the outflowing water has been made. Both of them enter the first aquifer complex.

\section{HYDROGEOLOGICAL SETTING}

The studied area of the terrace of Kamchiya River extends along the borders of the Lower Kamchiya foreland depression (Atanasov, 1971). In hydrogeological aspect, the tectonic structure represents a complex multi-layered aquifer system, relatively well studied during 1955-1962 due to oil and gas exploration campaigns. More than 60 exploration and exploitation boreholes for iodine-bromine water (Yovchev and Ryzhova, 1962) were drilled during this period. Two high-ranked pre-Neogene hydrogeological units with pressure waters overlap with a Neogene low-pressure aquifer complex (Table 1) with widespread revelations on the slopes of Kamchiya valley (Fig. 1). In its upper part, the multi-layered aquifer ends with a Quaternary aquifer complex, formed in the sediments of the Lower Kamchiya River's terrace. 
Table 1

Water in the pre-Quaternary sediments (after Yovchev and Ryzhova, 1962)

\begin{tabular}{|c|c|c|c|c|c|}
\hline $\begin{array}{c}\text { Hydrogeological } \\
\text { unit }\end{array}$ & \multicolumn{2}{|c|}{ Lithostratigraphic unit/subunit } & Lithology & $\begin{array}{l}\text { Transmissivity, } \\
\mathrm{m}^{2} / \mathrm{d}\end{array}$ & $\begin{array}{c}\text { TDS, } \\
\mathrm{g} / 1\end{array}$ \\
\hline $\begin{array}{l}\text { Neogene } \\
\text { aquifer complex }\end{array}$ & \multicolumn{2}{|l|}{$\begin{array}{l}\text { Galata } \\
\text { Formation }\end{array}$} & $\begin{array}{l}\text { conglomerates, sand- } \\
\text { stones, clays and marbles }\end{array}$ & $15.0-103.0$ & $<1.0$ \\
\hline \multirow{3}{*}{$\begin{array}{l}\text { Oligocene } \\
\text { aquifer complex }\end{array}$} & \multirow{3}{*}{$\begin{array}{l}\text { Ruslar } \\
\text { Formation }\end{array}$} & $3^{\text {rd }}$ package & $\begin{array}{l}\text { quartz sandstones and } \\
\text { siltstones }\end{array}$ & $1.8-2.0$ & $24.0-41.0$ \\
\hline & & $2^{\text {nd }}$ package & $\begin{array}{l}\text { sandstones and clayey } \\
\text { siltstones }\end{array}$ & N/A & $25.0-32.0$ \\
\hline & & $1^{\text {st }}$ package & $\begin{array}{l}\text { clays with sandstone and } \\
\text { siltstone layers }\end{array}$ & $17.0-29.0$ & $21.0-24.0$ \\
\hline \multirow{4}{*}{$\begin{array}{l}\text { Upper Eocene aqui- } \\
\text { fer complex }\end{array}$} & \multirow{4}{*}{$\begin{array}{l}\text { Dolni Chiflik } \\
\text { Formation }\end{array}$} & $4^{\text {th }}$ package & sandstones & $6.0-21.0$ & $<47.0$ \\
\hline & & $3^{\text {rd }}$ package & $\begin{array}{l}\text { fine-grained sandstones } \\
\text { and marls }\end{array}$ & $1.0-5.0$ & $20.0-24.0$ \\
\hline & & $2^{\text {nd }}$ package & sandstones & $0.8-6.0$ & $7.4-13.5$ \\
\hline & & $1^{\text {st }}$ package & sandstones and siltstones & 0.5 & $9-10$ \\
\hline
\end{tabular}

The Quaternary aquifer complex has thoroughly been studied over the past 50-60 years due to implementation of various production and environmental projects, construction of water wells, irrigation and drainage facilities, monitoring wells, etc. The results from the drilling studies show that the Quaternary complex consists of sediments of various origin, lithology and grain-size, with complex lateral relationships. Its thickness increases eastwards, from $25-30 \mathrm{~m}$ to $60 \mathrm{~m}$. The base of the complex is built up of highly permeable basal gravel, overlain by sea sand layers and old alluvial gravel, both permeable. The current alluvial-lake, alluvial and deluvial deposits (clay, sandy clays, peat, mud, etc.) are very poorly permeable, and in some places they serve as limited local aquitards. The lower aquitard consists of thick Neogene marls and is well exposed in the region. The alluvial gravel and sand, as well as sea sands, have high permeability, thus favouring both the convective transport of substance and intensive exchange capabilities. Hydraulic conductivity values increase from 15 $20 \mathrm{~m} / \mathrm{d}$ to $60 \mathrm{~m} / \mathrm{d}$ and more, from the west to the east, and the transmissivity values vary from $200-300 \mathrm{~m}^{2} / \mathrm{d}$ to about $2000 \mathrm{~m}^{2} / \mathrm{d}$. The main recharge of the Quaternary aquifer complex is from the Kamchiya River, but precipitation, irrigation and waters comes from the Neogene complex. The relationships between different lithologies of the Quaternary complex determine more complicated structure of the groundwater flow as well as rather specific conditions of water and mass exchange between layers with different water permeability as well as with the Kamchiya River and the Black Sea.

Groundwater in the Quaternary sediments is generally unconfined, only locally semi-confined to confined. The main factors controlling the variations of the Quaternary complex levels (hydraulic heads) are the Black Sea, the Kamchiya River and the facilities built in the 1950s (a system of irrigation and drain- age channels and wells for groundwater extraction). The total flow rate of the drainage channels is 500 $600 \mathrm{l} / \mathrm{s}$ and of the wells about $40 \mathrm{l} / \mathrm{s}$. Under natural conditions, the levels are situated $0.5-2.0 \mathrm{~m}$ below the surface, and the groundwater flow is generally directed towards the sea, with a hydraulic gradient of about 0.0012 . The natural structure of the stream is heavily deformed by the action of the irrigation and drainage system, as well as by the wells. Part of the stream is oriented towards the water extraction facilities in the central part of the area considered herein.

Groundwater in the Quaternary aquifer is cold and fresh, compositionally very similar to the waters of the Kamchiya River. The coastal area is saline, due to the intrusion of seawater, where a $1-2 \mathrm{~km}$ long salt wedge has been formed. Considerable salinization and compositional changes of groundwater and soils have been recorded in other sections of the Quaternary complex, quite away from the coastline. These phenomena are a result of the interaction of deep drilling during oil and gas exploration and irrigation-drainage channels. The penetration mechanism of salty waters from the depth is as follows: in natural conditions, there are no direct hydraulic links between the fresh waters in the Quaternary and the highly mineralized pressure waters in the Paleogene complexes at a depth of less than 500 $\mathrm{m}$. Such linkages are most likely due to poor-quality liquidation of deep drillings carried out between 1957 and 1974 and severe corrosion of their casing. Outflowing from these wells and currently highly mineralized waters cause local intensive salinization of the Quaternary complex. The channels cause lateral expansion of negative processes and changes in the fresh water composition of a much wider territory. The parameters of salinization from deep drilling are very impressive. Only one borehole yielded at least $600 \mathrm{~kg}$ of salt per year. This value, calculated for a period of 30 years, points to more than 18 tons of salt that have been imported into the region. 


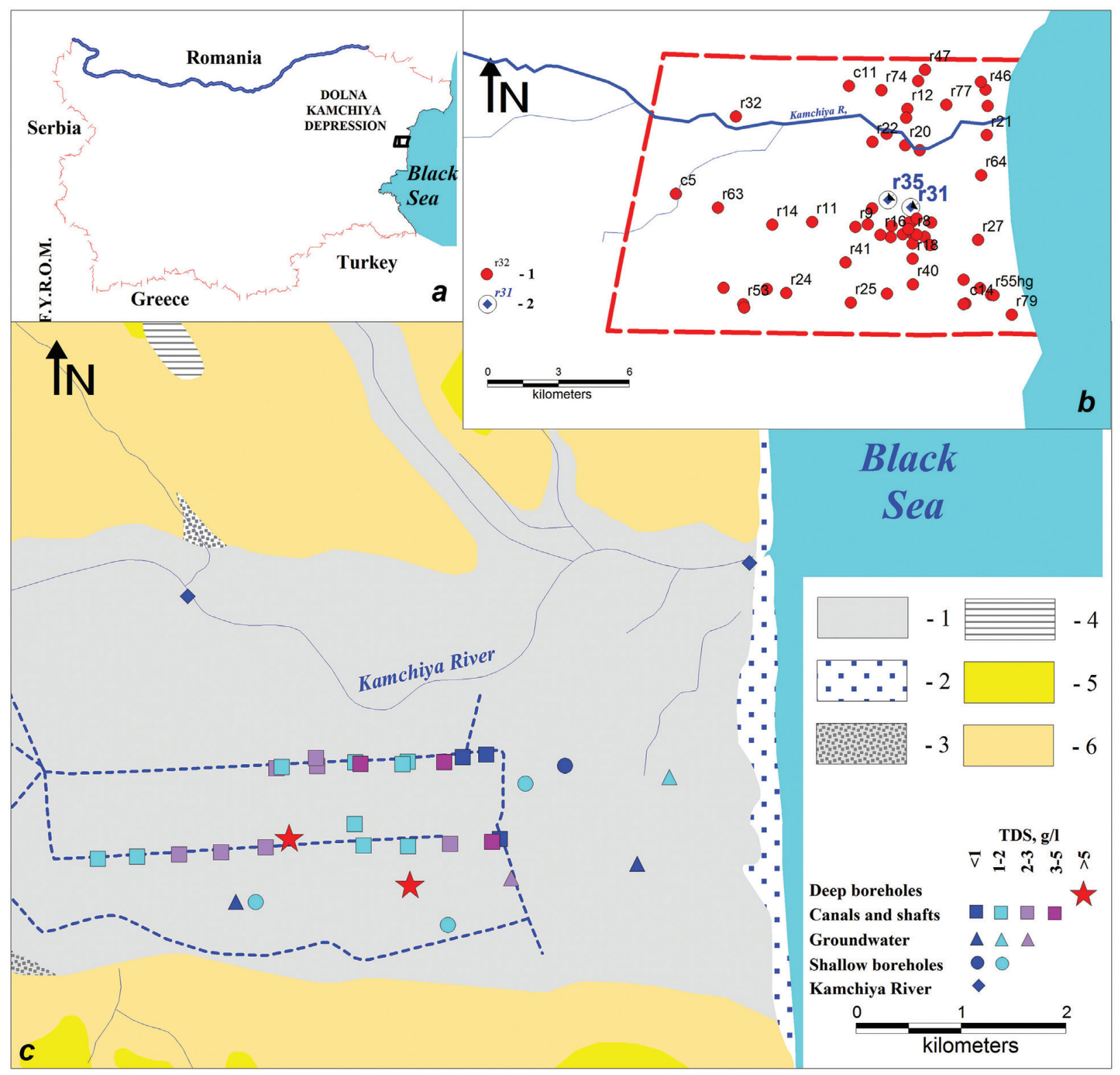

Fig. 1. Location of the studied area: $a$ ) Position of the Dolna Kamchiya foreland Depression; $b$ ) Boreholes in the Dolna Kamchiya Depression: 1 - boreholes; 2 - studied wells; c) Geological map of the Dolna Kamchiya Depression (after Cheshitev et al., 1992; Kanchev and Gercheva, 1992): 1 - alluvial deposits (pebble to gravel conglomerates, sands, clays and loess); 2 - beach sands; 3 drift sands, pebble to gravel conglomerates and clays; 4 - loess-like clays (Pleistocene); 5 - pebble to gravel conglomerates, sands and clays (Pliocene); 6 - conglomerates, sandstones, sands and clays (Tshokrakian).

Our studies of this phenomenon are focused on a representative strip of the Quaternary complex, where two of the deep boreholes (P-31 and P-35) are located (Fig. 2). The area is far enough from the sea to be affected by the sea water intrusion processes. Obtained data suggest that the enhanced salinization is a direct result of the penetration of highly mineralized waters from the deep-water Paleogene complexes, which guarantee the reliability of quantitative assessments of the impact of the deep wells on freshwater in the Quaternary. The approach applied herein includes a complex of different hydrochemical and geophysical methods and techniques.

\section{METHODS AND RESULTS OF THE HYDROCHEMICAL STUDIES}

To evaluate the extent and degree of salinization of the freshwater in the Quaternary due to the deep drilling, unpublished data from chemical analyses of about 100 water samples from surface water and groundwater, 


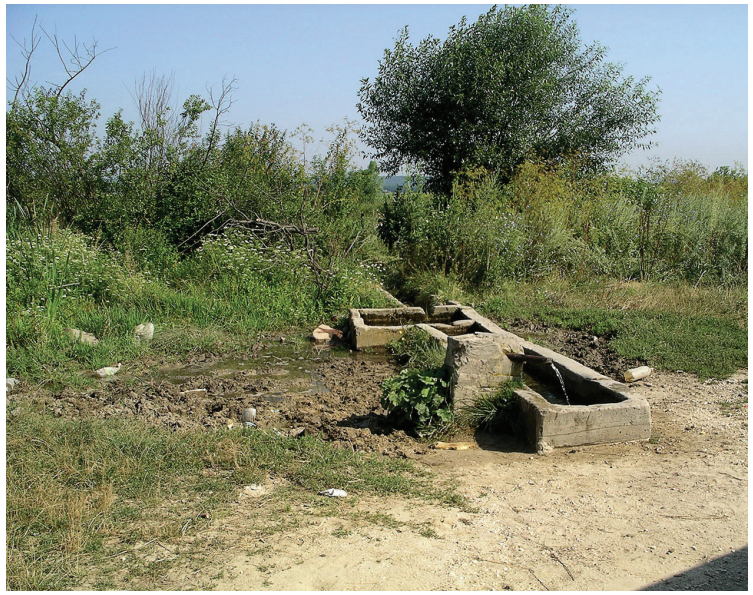

Fig. 2. Artesian wells P-31 (a) and P-35 (b).

including artesian deep wells, irrigation drainage channels, shafts, shrubs, tubing and shaft wells, monitoring wells and the Kamchiya River, have been used. The sampling was carried out contemporaneously with the detailed hydrogeological mapping in 1996 in the Lower Kamchiya River terrace (Stoyanov et al., 1997).

The chemical data of all samples was processed, using the AQUACHEM (Schlumberger Water Services) and Visual MINTEQ, which is a freeware chemical equilibrium model maintained by Jon Petter Gustafsson

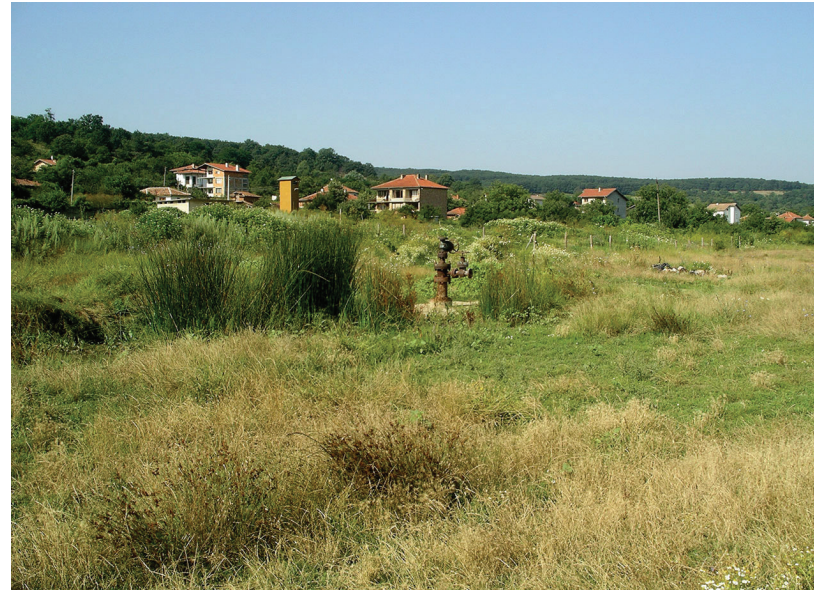

at the KTH Royal Institute of Technology, Sweden, with special attention paid to samples taken from the area of the artesian deep wells P-31 and P-35 (Fig. 3). Both wells were drilled in the period 1958-1959, at $1700 \mathrm{~m}$ and $1780 \mathrm{~m}$ depth respectively, and the outflowing water flows from the deep Paleogene aquifers. The selection of indicators and hydrochemical criteria for the identification and monitoring of the salinization processes is made by comparing the compositions of fresh water and water from the deep wells.

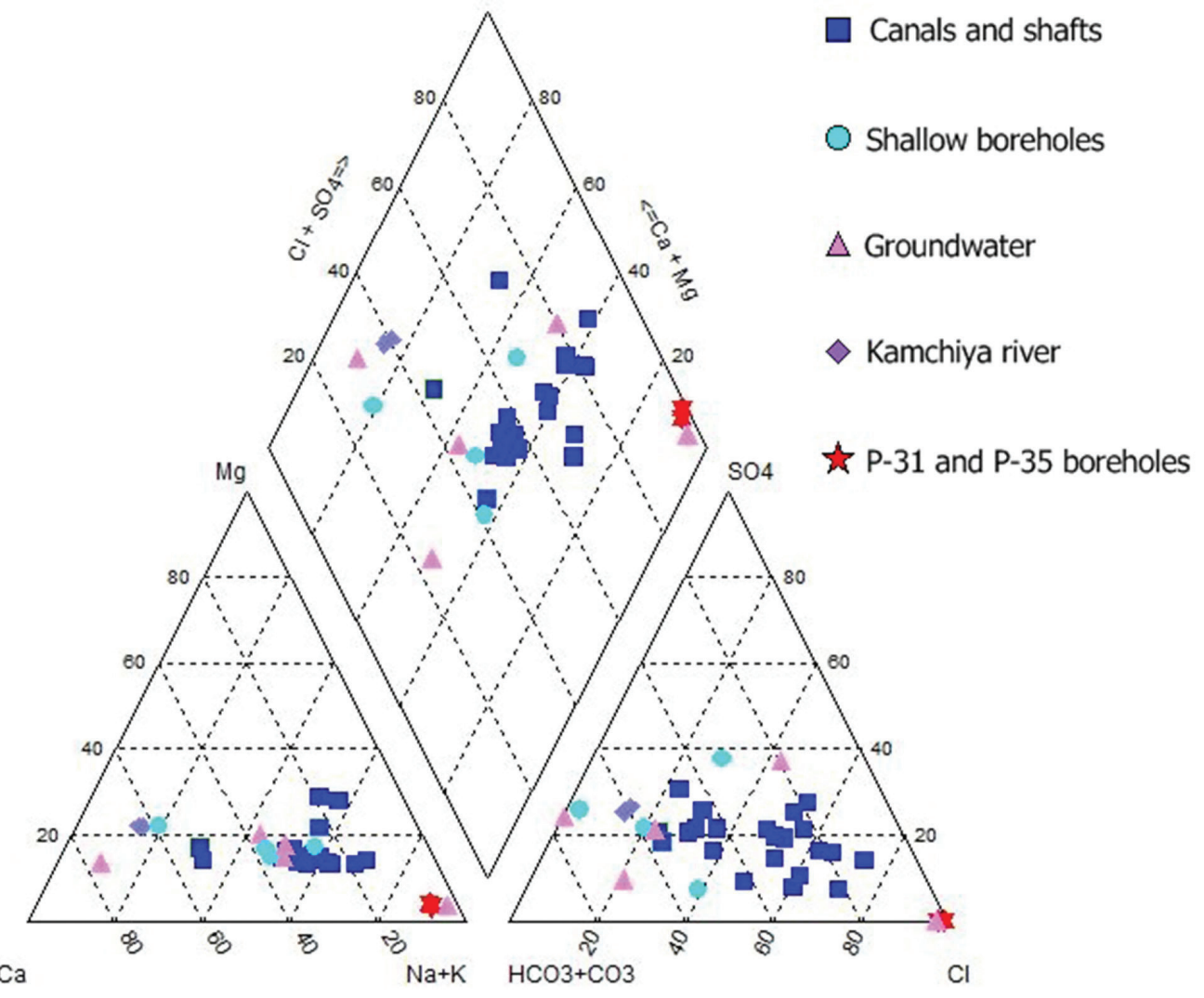

$\mathrm{Ca}$

$\mathrm{Na}+\mathrm{K}$
Cl
Fig. 3. Piper Diagram. 
The results from the hydrochemical study show that:

- The water of the Kamchiya River in the lower currents is $\mathrm{HCO}_{3}-\mathrm{SO}_{4}$ - $\mathrm{Ca}$, with a relatively low and constant mineralization between $445 \mathrm{mg} / 1$ and $610 \mathrm{mg} / \mathrm{l}$. Similar composition has the fresh groundwater in the Quaternary Complex as well, outside the area of the artesian wells. Their mineralization values are most often in the range of $400 \mathrm{mg} / 1$ to $600 \mathrm{mg} / \mathrm{l}$. Near the sea, in swampy areas or close to the artesian deep boreholes, the mineralization of the Quaternary waters is several times higher and reaches 2000$3000 \mathrm{mg} / \mathrm{l}$, even more. Concomitantly, the concentration of sodium and chlorine, and their importance in the formation of the groundwater type, increases sharply.

- The perennial and continuous outflowing of the deep-draining, highly mineralized P-31 and P-35 wells (with mineralization of $29.8 \mathrm{~g} / 1$ and $33.3 \mathrm{mg} / \mathrm{l}$, respectively) causes a coming-out of considerable amounts of chlorine, sodium, phosphates, calcium, magnesium, potassium, boron and many other chemical components. Over a period of 30 years, 50 tons of salt have been exported from the two wells, including ca $27.7 \mathrm{t}$ chlorine, $19.1 \mathrm{t}$ sodium, $1.1 \mathrm{t}$ calcium, $0.8 \mathrm{t}$ phosphates, $0.4 \mathrm{t}$ magnesium, $0.16 \mathrm{t}$ potassium. Around both wells, the effluent from their mouths has formed salty "ponds" that are drained through the drainage channels or infiltrated into the soil layer. In the monitoring sites (shafts, canals, wells, etc.), varying in quality surface and shallow groundwater is found, the chemical composition of which is a function of the distance and type of salt water sources (i.e., artesian wells or the sea).

- Salty water from deep wells also causes significant salinization of the soil layer. Forty soil samples were taken during the hydrogeological mapping in
1996, aiming to assess the extent of salinization of the affected areas. The soil layer around the P-31 and P-35 wells was tested up to $20 \mathrm{~cm}$ depth. The salinity of water extracts obtained by reacting soil samples with distilled water under static conditions was determined in laboratory conditions. Based on the results obtained around both wells, salted soils are mapped into an eastwest striking strip with an area of about $250 \mathrm{~km}^{2}$, where the salinity of the soil extracts ranges from $0.5 \mathrm{~g} / 1$ up to $\sim 13 \mathrm{~g} / 1$ or more.

\section{METHODS AND RESULTS OF THE GEOPHYSICAL STUDIES}

With purpose of preliminary assessment of the spatial boundaries and salinity level of the Quaternary aquifer complex, limited geophysical studies were carried out in the area of the P-31 and P-35 wells (Fig. 1). Three classical geoelectric methods were applied: the method of the charged body; electrotomography; and vertical electrical sounding (VES).

\section{Method of the charged body}

It is designed to study conductive heterogeneities crossed by drilling, mining or terrain (REF.). A major feature of the method is that one feeder electrode is placed in the conductive heterogeneity (here the borehole) and the other at a large distance in the so-called "infinity". The gradient methodology is applied with the receiving line $\mathrm{MN}=10 \mathrm{~m}$. According to the field measurements, maps of potential differences $(\Delta \mathrm{U})$ have been made, which outline the approximate lateral boundaries and the intensity of salinization around the boreholes (Fig. 4).

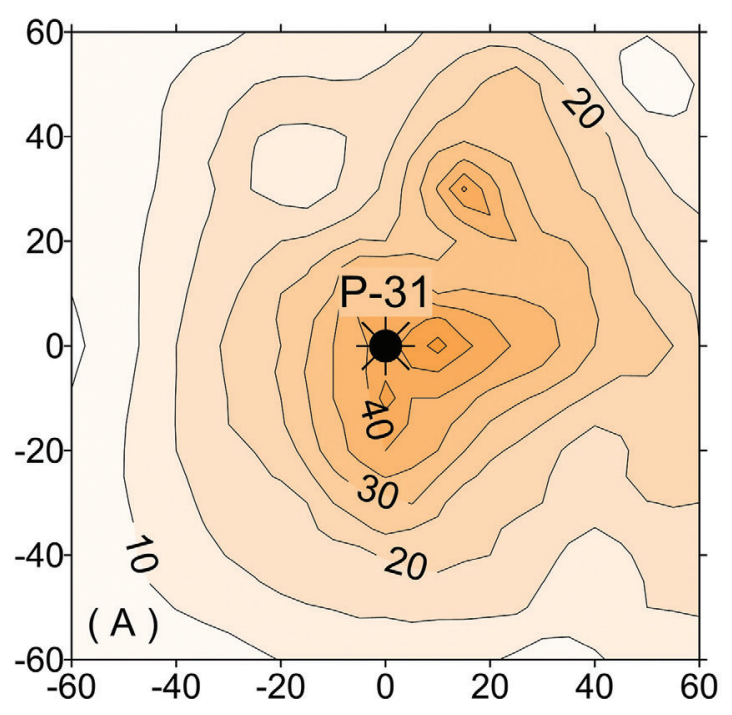

Fig. 4. Electro-geophysical map of potential differences.

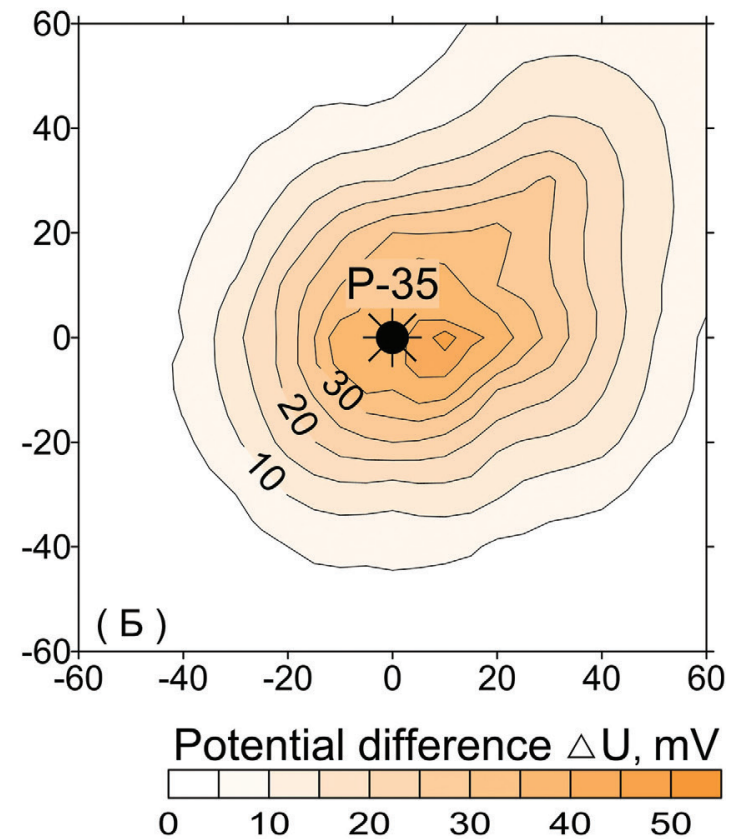




\section{Electrotomography}

A geoelectric mapping was carried out in a two-dimensional space. The chosen "pole-dipole" measurement circuit gives very good horizontal and vertical coverage and is highly susceptible to local inconsistencies. Measurements were processed by the RES2DINV program. In the obtained geoelectric incisions, the boundaries of the salt water, entering the surrounding area, are outlined up to $30 \mathrm{~m}$ depth (Fig. 5).

Criteria for marking a boundary between the saline water area around the wells and the mixed groundwater (salinized) area is $3000 \mathrm{mg} / \mathrm{l}$ total dissolved solids (TDS) content. The predominant gravel-sandy deposits in the Quaternary aquifer complex give reason to assume that the electrical resistances of the medium mapping the salty water area are in the range of $1 \mathrm{Ohm} \times \mathrm{m}$ to $10 \mathrm{Ohm} \times \mathrm{m}$.

\section{Vertical electrical sounding method}

The electromechanical scheme used has parameters $\mathrm{AB}_{\text {min }}=1.5 \mathrm{~m}, \mathrm{AB}_{\text {max }}=250 \mathrm{~m}$ and 10 points in the decade. The results of eight VES are presented in a linear order on a geophysical profile 1-1 with a length of
$2 \mathrm{~km}$, oriented in W-E direction, which coincides with the groundwater flow direction. By interpolating data from the interpretation curves, a geoelectric model of the subsurface space has been made up to $50 \mathrm{~m}$ depth. The transformation of the model into a salinization model of the Quaternary aquifer complex (Fig. 6) was carried out, using a key developed for this purpose (Table 2). The proposed key criteria are defined according to the specific hydrogeological, hydrochemical and technogenic conditions, partly using criteria for assessing the salinization of groundwater as a result of sea water intrusion (De Breuck et al., 1991; Stoyanov and Gyurov, 2004; Stoyanov et al., 2017).

\section{DICUSSION AND CONCLUSIONS}

The conducted hydrochemical studies supplemented with new data change the existing ideas about the genesis, forms and intensity of the impact of the deep-well drilling of highly mineralized waters in the region of Kamchiya River terrace.

The low permeability of the surface layer implies the formation of wide surface spills of salty waters near the wells. Some of these waters flow down the
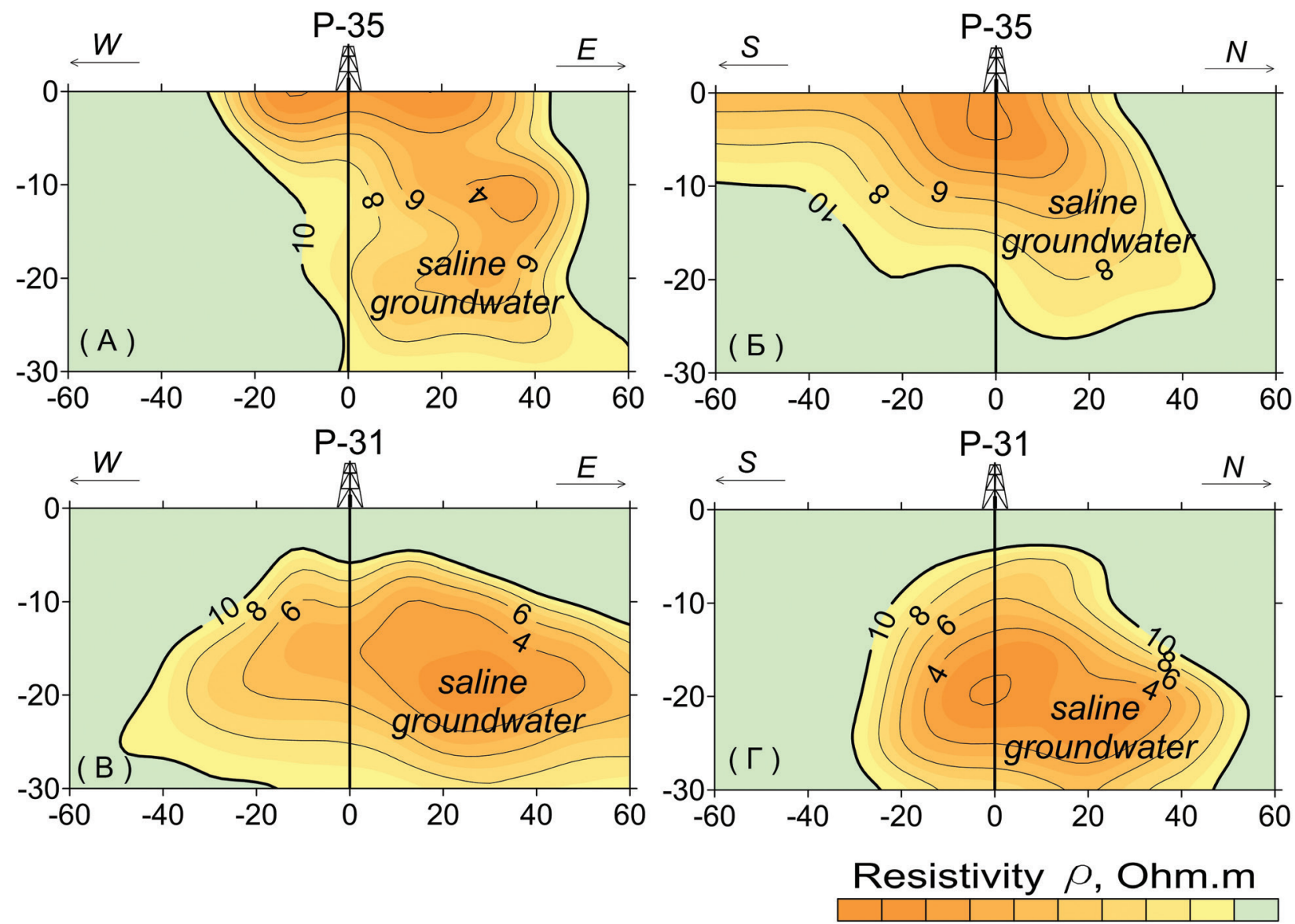

Fig. 5. Maps of salty waters. 

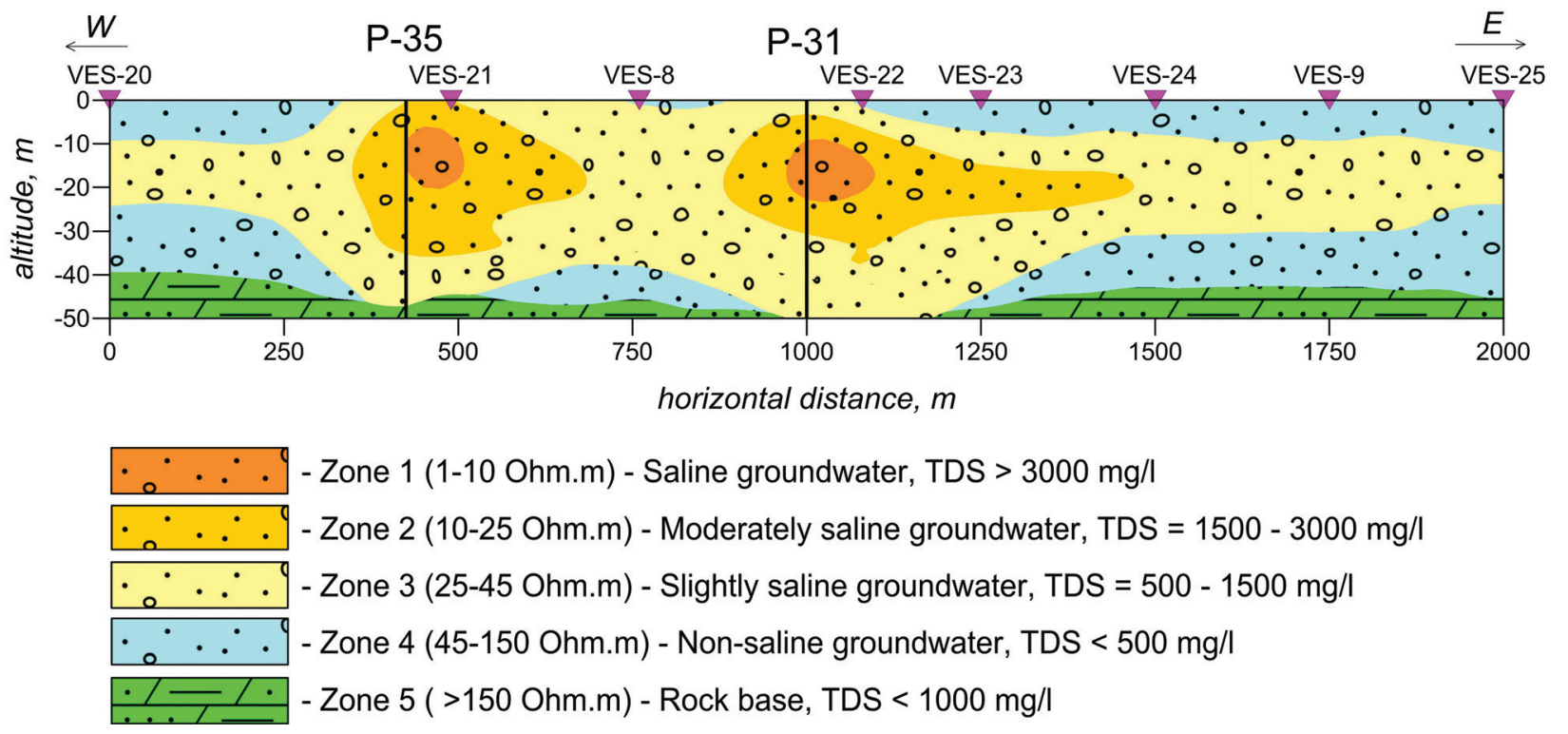

Fig. 6. Model of salinization of the Quaternary aquifer complex from the P-31 and P-35 wells.

Table 2

Criteria for transforming the geoelectric model into a salinity model

\begin{tabular}{c|l|l|c|c}
\hline \multirow{2}{*}{ Studied object } & \multicolumn{1}{|c|}{$\begin{array}{c}\text { Lithological } \\
\text { characteristics }\end{array}$} & \multicolumn{1}{|c|}{ Type of water } & TDS, mg/1 & $\begin{array}{c}\text { Electrical resistivity, } \\
\rho, \text { Ohm } \times \mathrm{m}\end{array}$ \\
\hline \multirow{3}{*}{ Quaternary aquifer } & \multirow{2}{*}{$\begin{array}{l}\text { Rubbles, sands } \\
\text { and clays }\end{array}$} & Highly saline & $>3000$ & $1-10$ \\
\cline { 3 - 5 } & Moderately saline & $1500-3000$ & $10-25$ \\
\cline { 2 - 4 } & \begin{tabular}{l} 
Slightly saline \\
\cline { 2 - 4 } Bedrock
\end{tabular} & Non-saline & $500-1500$ & $25-45$ \\
\hline
\end{tabular}

natural slope or the drainage channels. Others more slowly penetrate through the soil layer in depth to the groundwater. On their way, the surface-draining salty waters are diluted by precipitation and draining fresh groundwater in the canals. Away from the artesian wells, the role of mixing with unpolluted water grows to reach the near-background values of the observed indicators. The described scenario finds very reliable evidence in the results of water samples taken.

Surface spills saturate the soil layer near the artesian wells and subsequently infiltrate the level of groundwater. These processes, lasting for several decades, are the main reason for the salty soils to occupy larger areas. As a result, there was a permanent occurrence and, near the wells, irreversible damage of the soil cover on an area $\sim 5,000 \mathrm{~m}^{2}$. An important role for damaging the soil layer is the deposition of a substance from the highly mineralized waters. This process has changed the composition and structure of the soil, collated the surface layer and greatly hindered the infiltration of water in depth. Applying Visual MINTEQ, the probability of deposition of mineral phases around the wells is determined. The saturation index SI (Garrels and Christ, 1965) has been used as a criterion. At values for the corresponding mineral phase of SI $>0$, the waters are saturated with it and there is a probability of deposition; at SI $<0$, the waters are unsaturated and there are dissolution conditions. The results show that, in the spill area, the conditions favoured the deposition of 18 mineral phases at P-35 and 14 mineral phases at P-31 well. These are mainly different forms of $\mathrm{CaCO}_{3}$, as well as $\mathrm{Mg}, \mathrm{P}, \mathrm{Ba}, \mathrm{Mn}$-bearing minerals and others.

Salinization of groundwater in the Quaternary complex from deep wells is most likely achieved by: (1) direct entry of highly mineralized water into the Quaternary area through severely corroded areas, structural disturbances or defects in the casing of the deep wells; (2) saltwater infiltration in the spill area; (3) direct water and mass exchange between surface and groundwater in the area of drainage channels; and (4) remobilization of pollutants from the soil layer due to rainwater infiltration. Based only on hydrochemical 

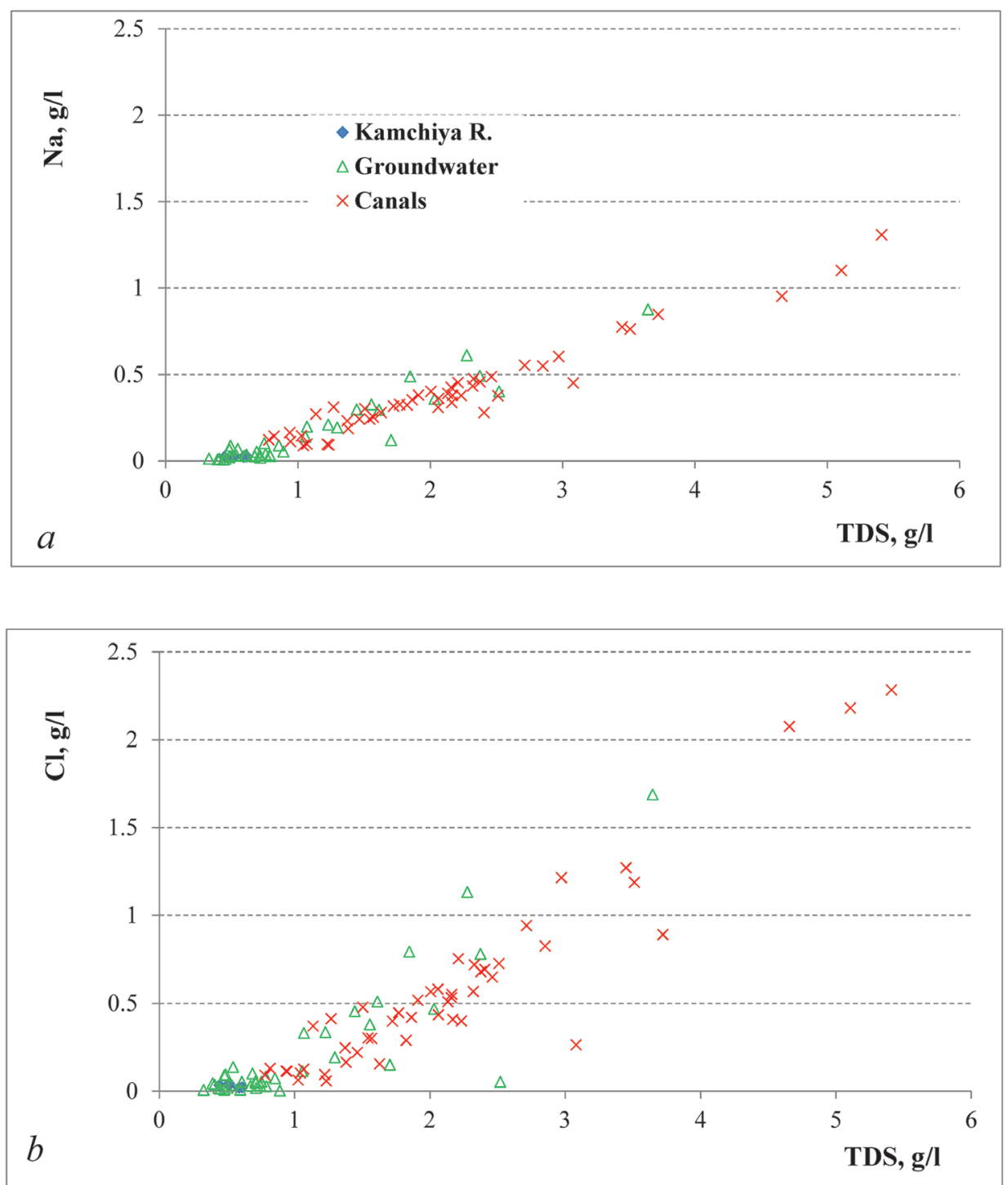

Fig. 7. Dependence between $\mathrm{Na}^{+}(a)$ and $\mathrm{Cl}^{-}(b)$ versus TDS.

data, the integral spatial impact of highly mineralized water on the fresh groundwater is difficult to assess due to insufficient observation sites (boreholes, wells, etc.) in the zone of potential impact of deep wells. Therefore, the assessment is made by application of geophysical methods based on the differences in electrical resistances between fresh and salty waters. It has been determined that the salt zone (with TDS $>3000$ $\mathrm{mg} / \mathrm{l}$ ) has a small spatial distribution and affects limited plots around deep wells at a depth between $10 \mathrm{~m}$ and $20 \mathrm{~m}$ below the surface. The salted area with TDS of $1000 \mathrm{mg} / \mathrm{l}$ to $3000 \mathrm{mg} / \mathrm{l}$ is more widespread, determined by the direction of groundwater flow and the "trail" of this area in the direction of the flow reaches $300 \mathrm{~m}$ from P-35 and $500 \mathrm{~m}$ from P-31. In direction opposite to the groundwater flow, the saline area extends up to 50-100 $\mathrm{m}$ from the boreholes.
Most important for the increasing of TDS content in surface water and groundwater are the most mobile and well-soluble sodium and chlorine ions (Fig. 7).

\section{Acknowledgements}

The recent study present results of the project "Exploration of the surface and groundwater interaction in the eastern half of the Kamchiya River terrace and its role on the water regime of Kamchiya Reserve in natural and disturbed conditions", 1997, funded by the Swiss League for the Protection of Nature - Basel, supplemented and interpreted by Project in the framework of the Program for Supporting Young Scientists and PhD Students of the BAS - 2017 "Exploration of the Status and Impact of Exploding Waters from Old Oil Drills". We are grateful for this. 


\section{REFERENCES}

Atanassov, A. 1971. Lower-Kamchiya foreland depression. In: Yovchev, Y. (Ed).The Tectonic Structure of Bulgaria. Tehnika, Sofia, 170-171 (in Bulgarian).

Cheshitev, G., Milanova, V., Popov, N., Kojumdgieva, E. 1992. Geological map of the Republic of Bulgaria M 1:100 000, Varna and resort Golden Sands map sheet. Committee on Geology, Company for Geophysical surveys and Geological mapping, Sofia.

De Breuck, W. (Ed.). 1991. Hydrogeology of salt water intrusion: a selection of SWIM papers, a report of the Commission on Hydrogeology of the International Association of Hydrogeologists. International Contributions to Hydrogeology 11, H. Heise, Hannover, 422 pp.

Garrels, R.M., Christ, C.L. 1965. Solution, minerals and equilibria. Harper and Row, New York, 450 pp.

Gustafson, J.P. 2004. Visual MINTEQ, Version 3.1. KTH Royal Institute of Technology, Stockholm (https://vminteq. lwr.kth.se).
Kanchev, I., Gercheva, R. 1992. Geological map of the Republic of Bulgaria M 1:100 000, Dolni Chiflik map sheet. Committee on Geology, Company for Geophysical surveys and Geological mapping, Sofia.

Stoyanov, N., Gyurov, Ch. 2004. Application of electrical resistivity surveying for estimating the salt water intrusion into the Quaternary aquifer in the region of Arkoutino reserve, Bulgaria Proceedings of the $4^{\text {th }}$ National Geophysical Conference with International Participation "Geophysics and Environment", 137-140.

Stoyanov, N., Gerginov, P., Tarabees, E., Benderev, A., Dimovski, S. 2017. State of the art and problems of interaction between groundwater and marine waters in the Nile delta - District Rashid, Egypt. Proceedings of the $17^{\text {th }}$ International Multidisciplinary Scientific GeoConference "SGEM 2017", 793-800.

Yovchev, R., Ryzhova. E. 1962. Groundwater in Northern Bulgaria. Main Directorate for Geology and Subsoil Protection, Sofia, 222 pp. (in Russian). 